\title{
Implementasi Algoritma Apriori pada Tata Letak Kategori Buku di Perpustakaan
}

\author{
Al Fiyan Nizaela Falahie ${ }^{1)}$, Teguh Susyanto ${ }^{2)}$, Retno Tri Vulandari ${ }^{3 *}$. \\ 1)2) Informatika, STMIK Sinar Nusantara \\ 3)* Teknologi Informasi, STMIK Sinar Nusantara \\ 1) $16500048 . f i y a n @$ sinus.ac.id,${ }^{2)}$ teguh@ sinus.ac.id , 3)* $\underline{\text { retnotv@ sinus.ac.id }}$
}

\begin{abstract}
The library is a collection place of various kinds of books. Arrangement of books by category called book shelving makes easier for customers to choose and find books. However, the location and arrangement of book categories becomes a problem in a library. Based on the book borrowing data, data mining was carried out to find out a book borrowed simultaneously by library visitor in one transaction. This can be solved by using the association rule technique and a priori algorithm. Possible combinations of borrowed books were based on certain rules and then tested whether the combination of items meets the minimum support requirements to create eligible rules. The results of this study were in the form of information about a combination of borrowed books for libraries to arrange the location of books according to categories that are often borrowed together.
\end{abstract}

Keywords: Apriori Algorithm, Association Rule, Book Shelving, Book Layout, Data Mining.

\section{PENDAHULUAN}

Analisis asosiasi atau association rule mining adalah teknik data mining untuk menemukan aturan asosiatif antara kombinasi item (Lingga, 2016). Penting tidaknya suatu asosiasi dapat diketahui dengan dua tolak ukur, yaitu: support dan confidence. Support (nilai penunjang) adalah persentase kombinasi item tersebut dalam database, sedangkan confidence (nilai kepastian) adalah kuatnya hubungan antar- item dalam aturan asosiasi (Sari, 2018).

Algoritma apriori merupakan salah satu algoritma yang digunakan untuk menemukan pola frekuensi tinggi yang sangat terkenal. Pola frekuensi tinggi merupakan pola-pola item di dalam suatu database yang memiliki frekuensi atau support di atas ambang batas tertentu yang disebut dengan istilah minimum support. Pola frekuensi tinggi ini digunakan untuk menyusun aturan asosiatif dan juga beberapa teknik data mining lainnya. Aturan yang menyatakan asosiasi antara beberapa atribut sering disebut sebagai affinity analysis atau market basket analysis (Hernawati, 2018).

Perpustakaan merupakan salah satu fasilitas penyedia informasi, sebagai sumber ilmu pengetahuan, serta sarana penunjang proses kegiatan belajar mengajar bagi para pengguna untuk mendapatkan informasi yang diinginkan (Persia \& Rohmiyati, 2013). Ketika perpustakaan menyesuaikan dengan perkembangan zaman, mereka membutuhkan pengetahuan sebagai acuan untuk menggambarkan kondisi lingkungan serta solusi untuk mengatasinya. Selain itu, sudah menjadi masalah bersama bahwa perpustakaan beserta pustakawannya belum dapat sepenuhnya memenuhi kebutuhan pengguna, seperti tidak ada interaksi selain hanya tanya jawab di front office, rekomendasi koleksi kepada pengguna belum terakomodasi, pustakawan cenderung tidak mengetahui koleksi apa yang sedang trend dan populer atau yang dibutuhkan pengguna dan koleksi apa yang direkomendasikan di perpustakaan (Pracoyo \& Seniwati, 2021).

Fokus pustakawan yang seperti itu terindikasi bahwa perkembangan pengetahuannya mengenai dunia perpustakaan serta dunia pengguna sebatas mengelola dan melayankan koleksi, belum pada pelayanan merekomendasikan koleksi dan membantu memecahkan masalah yang dihadapi pengguna (Anas, 2014). Tujuan penelitian ini adalah merancang, 
membangun, mengimplementasikan, dan menerapkan sistem algoritma apriori pada data transaksi peminjaman buku di perpustakaan yang dapat dijadikan rekomendasi peminjaman buku.

\section{TINJAUAN PUSTAKA}

\subsection{Data Mining}

Pemanfaatan data yang ada di dalam sistem informasi untuk menunjang kegiatan pengambilan keputusan tidak cukup hanya mengandalkan data operasional saja, tetapi diperlukan suatu analisis data untuk menggali potensi-potensi informasi yang ada. Para pengambil keputusan berusaha untuk memanfaatkan gudang data yang sudah dimiliki dalam mengambil keputusan, hal ini mendorong munculnya cabang ilmu baru untuk mengatasi masalah penggalian informasi atau pola yang penting dan menarik dari data jumlah besar, yang disebut dengan data mining (Jollyta, Ramdhan, \& Zarlis, 2020). Data mining adalah serangkaian proses untuk menggali nilai tambah berupa informasi yang selama ini tidak diketahui secara manual dari suatu basis data (Vulandari, 2017). Data mining disebut juga Knowledge Discovery in Database (KDD) didefinisikan sebagai ekstraksi informasi potensial, implisit dan tidak dikenal dari sekumpulan data. Proses Knowlegde Discovery in Database melibatkan hasil proses pengekstrak kecenderungan suatu pola data, kemudian mengubah hasilnya secara akurat menjadi informasi yang mudah dipahami (Lestari, 2017).

\subsection{Algoritma Apriori}

Algoritma apriori adalah suatu algoritma dasar yang diusulkan oleh Agrawal \& Srikant pada tahun 1994 untuk penentuan frequent item sets untuk aturan asosiasi Boolean. Algoritma apriori termasuk jenis aturan asosiasi pada data mining dan aturan yang menyatakan asosiasi antara beberapa atribut sering disebut market basket analysis (Tahyudin, Putra, \& Syafa'at, 2021). Analisis asosiasi adalah teknik data mining untuk menemukan aturan asosiasi antara suatu kombinasi item. Salah satu tahap analisis asosiasi yang menarik perhatian banyak peneliti untuk menghasilkan algoritma yang efisien adalah analisis pola frekuensi tinggi (Suendri, Ikhwan, \& Hutabarat, 2021). Penting tidaknya suatu asosiasi dapat diketahui dengan dua tolak ukur, yaitu: support dan confidence. Support (nilai penunjang) adalah persentase kombinasi item tersebut dalam database, sedangkan confidence (nilai kepastian) adalah kuatnya hubungan antar-item dalam aturan asosiasi (Ariyanti, 2020).

Kedua ukuran (support dan confidence) berguna untuk menetukan batasan yang ditentukan oleh pengguna. Batasan tersebut umumnya terdiri atas minimum support sebagai batasan minimum dari nilai support dan minimum confidence sebagai batasan nilai confidence (Siregar \& Puspabhuana, 2020). Langkah-langkah dalam pembentukan aturan asosiasi ada 2 tahapan yaitu:

1. Analisa pola frekuensi tinggi

Tahap ini mencari kombinasi item yang memenuhi syarat minimum dari nilai support dalam database. Nilai support sebuah item diperoleh dengan rumus yang diperihatkan pada rumus berikut:

$$
\text { Support }(A)=\frac{\text { Jumlah transaksi mengandung A }}{\text { Total transaksi }} \times 100 \%
$$

sedangkan nilai support dari 2 item diperoleh dari rumus 2 yang diperihatkan pada rumus berikut:

$$
\text { Support }(A \cap B)=\frac{\text { Jumlah transaksi mengandung A dan B }}{\text { Total transaksi }} \times 100 \%
$$


2. Pembentukan aturan asosiasi

Setelah semua pola frekuensi tinggi ditemukan, dicari aturan asosiasi yang memenuhi syarat minimum untuk confidence dengan menghitung confidence aturan asosiasi $\mathrm{A} \longrightarrow \mathrm{B}$. Nilai confidence dari aturan $\mathrm{A} \longrightarrow \mathrm{B}$ diperoleh dari rumus yang diperihatkan pada rumus berikut:

$$
\text { confidence }(B \mid A)=P(B \mid A)=\frac{\text { Jumlah transaksi A dan B }}{\text { Jumlah transaksi A }} \times 100 \%
$$

(Fitrina, Kustanto, \& Vulandari, 2018)

\section{METODE PENELITIAN}

Metode penelitian merupakan prosedur dan teknik penelitian. Antara satu penelitian dan penelitian lain, prosedur dan tekniknya akan berbeda. Kalau tidak berbeda berarti penelitian itu hanya mengulang penelitian yang telah ada sebelumnya. Dalam penelitian untuk menentukan sistem rekomendasi peminjaman buku di perpustakaan, peneliti menggunakan algoritma apriori dengan menggunakan metode asosiasi untuk rekomendasi berdasarkan kategori buku yang sering dipinjam. Untuk membuat aplikasi sistem perekomendasian buku tersebut, peneliti membutuhkan data transaksi peminjaman buku di perpustakaan selama 1 bulan. Data yang diambil 15 kategori buku yaitu Komik, Agama, Psikologi, Anak-anak, Komputer dan Teknologi, Pendidikan, Fiksi, Sejarah, Travel, Keluarga, Buku Masakan, Hukum, Bisnis dan Ekonomi, Finansial, serta Pertanian. Metode pengumpulan data yang dilaksanakan oleh penulis ialah observasi, wawancara dan studi pustaka.

Langkah-langkah yang dilakukan dalam perhitungan untuk menentukan asosiasi pola penjualan sebagai berikut:

1. Memasukkan data kategori dan data transaksi

2. Menentukan nilai minimum support, confidence, dan jumlah transaksi

3. Hitung frekuensi support item

4. Hitung confidence

5. Pembentukan aturan asosiasi final

Hasil perhitungan tersebut berupa aturan asosiasi final kategori buku berdasarkan data transaksi peminjaman buku. Berikut flowchart algoritma apriori ditunjukkan pada Gambar 1.

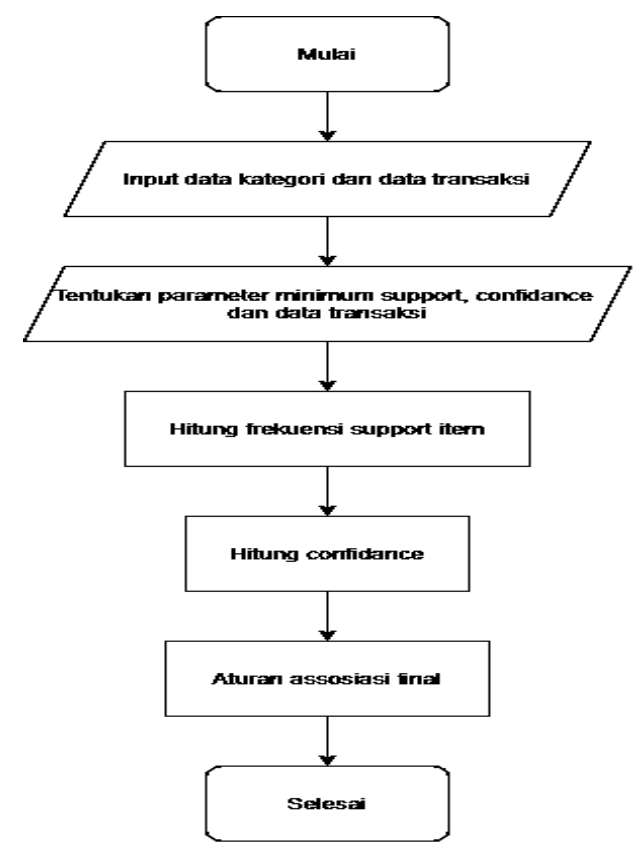

Gambar 1. Flowchart Algoritma Apriori 


\section{HASIL DAN PEMBAHASAN}

Hal ini akan dibahas secara detail dan terperinci mengenai aplikasi sistem yang akan diimplementasikan dengan menerapkan metode penelitian yang telah diuraikan pada pembahasan ini tahapan yang akan dibahas yaitu langkah perhitungan, desain sistem, implementasi sistem, serta pengujian sistem.

\section{1. Algoritma Apriori}

Langkah perhitungan Algoritma Apriori dalam penelitian ini adalah sebagai berikut:

1. Kategori buku

Setiap kategori buku yang ada pada transaksi peminjaman buku ditunjukan pada Tabel 1.

Tabel 1. Daftar Kategori Buku

\begin{tabular}{|c|l|c|}
\hline No. & \multicolumn{1}{|c|}{ Nama Kategori } & Kode \\
\hline 1 & KOMIK & KMK \\
\hline 2 & AGAMA & AGM \\
\hline 3 & PSIKOLOGI & PSG \\
\hline 4 & ANAK-ANAK & ANK \\
\hline 5 & KOMPUTER \& TEKNOLOGI & KTI \\
\hline 6 & PENDIDIKAN & PND \\
\hline 7 & FIKSI & FKS \\
\hline 8 & SEJARAH & SJR \\
\hline 9 & TRAVEL & TRV \\
\hline 10 & KELUARGA & KLG \\
\hline 11 & BUKU MASAKAN & BMS \\
\hline 12 & HUKUM & HKM \\
\hline 13 & BISNIS \& EKONOMI & BEK \\
\hline 14 & FINANSIAL & FNS \\
\hline 15 & PERTANIAN & PTN \\
\hline
\end{tabular}

2. Pola transaksi

Berdasarkan data transaksi peminjaman buku pada Perpustakaan Ganesa yang dipinjam secara bersamaan selama bulan Januari 2020 secara bersamaan ditunjukan pada Tabel 2.

Tabel 2.Pola transaksi peminjaman buku secara bersamaan

\begin{tabular}{|c|l|l|}
\hline No & \multicolumn{1}{|c|}{ Tanggal } & \multicolumn{1}{|c|}{ Transaksi } \\
\hline 1 & 1 Jan 2020 & Komik, Fiksi \\
\hline 2 & 1 Jan 2020 & Sejarah, Pendidikan \\
\hline 3 & 1 Jan 2020 & Keluarga, Buku Masakan \\
\hline 4 & 1 Jan 2020 & Fiksi, Pendidikan \\
\hline$\ldots \ldots$ & $\ldots \ldots \ldots \ldots \ldots$ & $\ldots \ldots \ldots \ldots \ldots \ldots \ldots \ldots \ldots \ldots \ldots \ldots \ldots \ldots$ \\
\hline 251 & 31 Jan 2020 & Sejarah, Agama \\
\hline 252 & 31 Jan 2020 & Fiksi, Komik \\
\hline 253 & 31 Jan 2020 & Fiksi, Komik \\
\hline
\end{tabular}


3. Support 1 itemset

Pembentukan 1 Itemset Proses pembentukan $\mathrm{C} 1$ atau disebut dengan 1 itemset dengan jumlah minimum support $=15 \%$. Berikut merupakan perhitungan pembentukan 1 itemset dengan menggunakan persamaan (1):

$$
\text { Support KMK }=\frac{109}{253} \times 100 \%=43,08 \%
$$

Minimum support yang ditentukan ialah 15\%, maka kombinasi 1-itemset yang memenuhi dapat dilihat seperti Tabel 3.

Tabel 3. Support dari 1 itemset

\begin{tabular}{|c|l|c|}
\hline No. & Nama Kategori & Support \\
\hline 1 & KMK & $43,9 \%$ \\
\hline 2 & KTI & $15,4 \%$ \\
\hline 3 & PND & $53,4 \%$ \\
\hline 4 & FKS & $42,7 \%$ \\
\hline 5 & SJR & $17,8 \%$ \\
\hline
\end{tabular}

4. Support 2 itemset

Kombinasi 2 itemset, proses pembentukan $\mathrm{C} 2$ atau disebut dengan 2 itemset dengan jumlah minimum support $=15 \%$. Berikut merupakan perhitungan pembentukan $\mathrm{C} 2$ atau 2 itemset menggunakan persamaan (2).

$$
\text { Support KMK \& PND }=\frac{39}{253} \times 100 \%=15,4 \%
$$

Minimum support yang ditentukan ialah 15\%, maka kombinasi 2-itemset yang memenuhi dapat dilihat seperti Tabel 4.

Tabel 4. Support dari 2 itemset

\begin{tabular}{|c|l|r|}
\hline No. & \multicolumn{1}{|c|}{ Nama Kategori } & \multicolumn{1}{c|}{ Support } \\
\hline 1 & KMK, PND & $15,4 \%$ \\
\hline 2 & KMK, FKS & $23,3 \%$ \\
\hline
\end{tabular}

5. Support 3 itemset

Kombinasi 3 itemset, proses pembentukan C3 atau disebut dengan 3 itemset dengan jumlah minimum support $=15 \%$. Berikut merupakan perhitungan pembentukan $\mathrm{C} 3$ atau 3 itemset.

$$
\text { Support KMK, PND, FKS }=\frac{39}{253} \times 100 \%=15,4 \%
$$

Minimum support yang ditentukan ialah15\%, maka kombinasi 3-itemset yang tidakmemenuhi dapat dilihat seperti Tabel 5.

Tabel 5. Support dari 3 itemset

\begin{tabular}{|c|l|r|}
\hline No. & Nama Kategori & Support \\
\hline 1 & KMK, PND, FKS & $15,4 \%$ \\
\hline
\end{tabular}




\section{Aturan Asosiasi}

Menentukan strong rule dari frequent itemset, dalam tahapan ini sering disebut pembentukan aturan asosiasi. Setelah semua pola frekuensi tinggi telah ditemukan, langkah selanjutnya peneliti mencari aturan asosiasi yang memenuhi syarat minimum confidence yang ditentukan adalah $30 \%$. Nilai confidence dari aturan $\mathrm{A} \rightarrow \mathrm{B}$ diolah dengan mengacu pada persamaan (3) dapat diselesaikan dengan perhitungan sebagai berikut.

$$
\text { Confidence KMK, PND }=\frac{39}{109} \times 100 \%=35,8 \%
$$

Minimum confidence yang ditentukan 30\%, maka kombinasi 2-itemset yang memenuhi minimum confidence dapat dilihat pada Tabel 6.

Tabel 6. Aturan Asosiasi 2itemset

\begin{tabular}{|c|l|c|c|}
\hline No. & \multicolumn{1}{|c|}{ Aturan } & \multicolumn{2}{c|}{ Confidence } \\
\hline 1 & $\begin{array}{l}\text { Jika meminjam kategori buku Komik, } \\
\text { maka akan meminjam kategori } \\
\text { Pendidikan }\end{array}$ & $39 / 109$ & $35,8 \%$ \\
\hline 2 & $\begin{array}{l}\text { Jika meminjam kategori buku } \\
\text { Pendidikan, maka akan meminjam } \\
\text { kategori Komik }\end{array}$ & $39 / 135$ & $28,9 \%$ \\
\hline 3 & $\begin{array}{l}\text { Jika meminjam kategori buku Komik, } \\
\text { maka akan meminjam kategori Fiksi }\end{array}$ & $59 / 109$ & $54,1 \%$ \\
\hline 4 & $\begin{array}{l}\text { Jika meminjam kategori buku Fiksi, } \\
\text { maka akan meminjam kategori Komik }\end{array}$ & $59 / 108$ & $54,6 \%$ \\
\hline
\end{tabular}

\section{Aturan Asosiasi Final}

Berdasarkan dari aturan asosiasi 2 itemset yang telah ditemukan maka itemset yang memenuhi nilai minimum support $15 \%$ dan minimum confidence $30 \%$ dapat dilihat pada Tabel 7.

Tabel 7. Aturan Asosiasi Final

\begin{tabular}{|c|l|c|c|}
\hline No. & \multicolumn{1}{|c|}{ Nama Kategori } & Support & Confidence \\
\hline 1 & $\begin{array}{l}\text { Jika meminjam kategori buku } \\
\text { Komik, maka akan meminjam } \\
\text { kategori Pendidikan }\end{array}$ & $15,4 \%$ & $35,8 \%$ \\
\hline 2 & $\begin{array}{l}\text { Jika meminjam kategori buku } \\
\text { Komik maka akan meminjam } \\
\text { kategori Fiksi }\end{array}$ & $23,3 \%$ & $54,1 \%$ \\
\hline 3 & $\begin{array}{l}\text { Jika meminjam kategori buku } \\
\text { Fiksi, maka akan meminjam } \\
\text { kategori Komik }\end{array}$ & $23,3 \%$ & $54,6 \%$ \\
\hline
\end{tabular}

\section{2. Desain Sistem}

\section{Desain Sistem}

Sebelum membuat sistem maka perlu adanya sebuah desain, agar pembuatan sistem tersebut sesaui dengan apa yang direncanakan. Desain sistem sangat diperlukan untuk memberikan gambaran bagaimana suatu sistem tersebut bekerja. Kebutuhan hardware dan arsitektur sistem secara keseluruhan bisa diketahui melalui desain sistem. 
Tahap ini sangat membantu dalam pembuatan sistem, bagaimana sistem tersebut akan berjalan dan mengetahui bagaimana output yang akan dihasilkan.

2. Unified Modeling Language (UML)

UML merupakan suatu bahasa spesifikasi standar yang bertujuan untuk mendokumentasikan, menspesifikasikan, dan membangun sistem perangkat lunak. UML dapat digunakan untuk memahami dan mendokumentasikan setiap alur yang terjadi dalam suatu sistem.

\section{3. Implementasi Sistem}

Sistem diimplementasikan kedalam web aplikasi yang telah didesain menggunakan bahasa pemrograman PHP, HTML, CSS, dan menggunakan database MySQL server dari XAMPP. Menggunakan text editor, sublime text 3.

1. Tampilan Halaman Login

Setiap kali user mengakses aplikasi ini maka akan tampil halaman login. Halaman login berisi inputan username dan password serta tombol login. Berikut ini merupakan tampilan dari halaman login yang terlihat seperti Gambar 2.

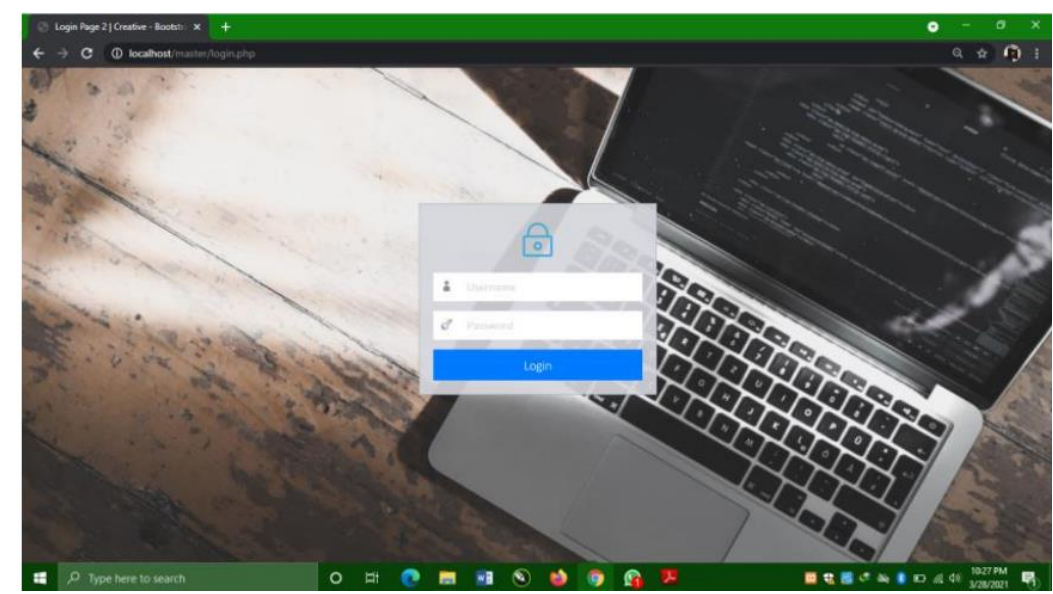

Gambar 2. Tampilan Halaman Login

2. Tampilan Halaman Home

Pada tampilan menu home terdapat menu-menu yang dapat diakses oleh administrator. Tampilan menu home dapat dilihat pada Gambar 3.

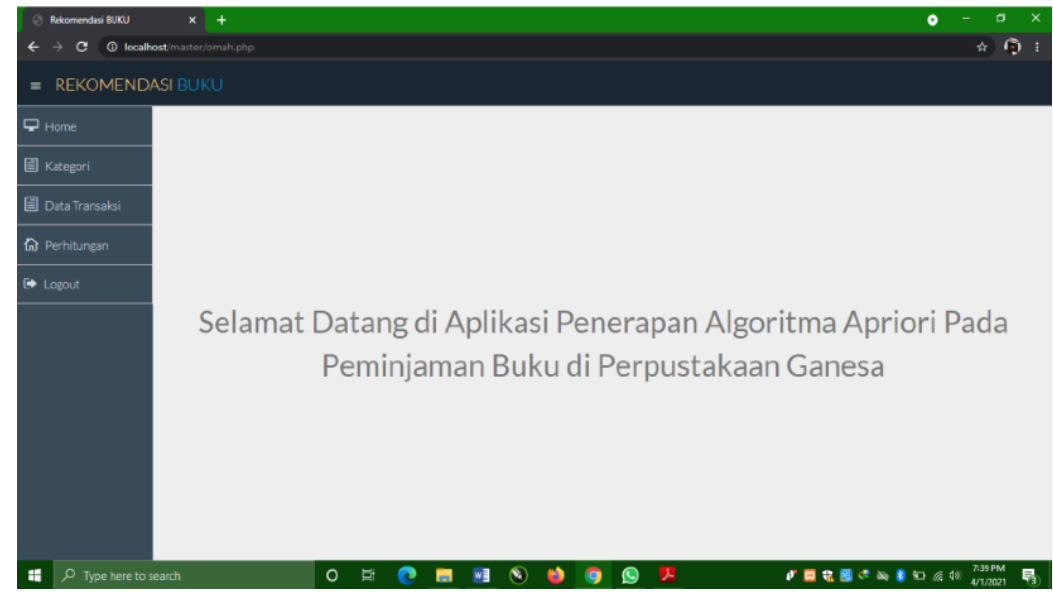

Gambar 3. Tampilan Halaman Home 
3. Tampilan Halaman Kategori

Pada tampilan menu kategori, administrator dapat mengolah data kategori yang ada di Perpustakaan Ganesa. Tampilan menu kategori dapat dilihat pada Gambar 4.

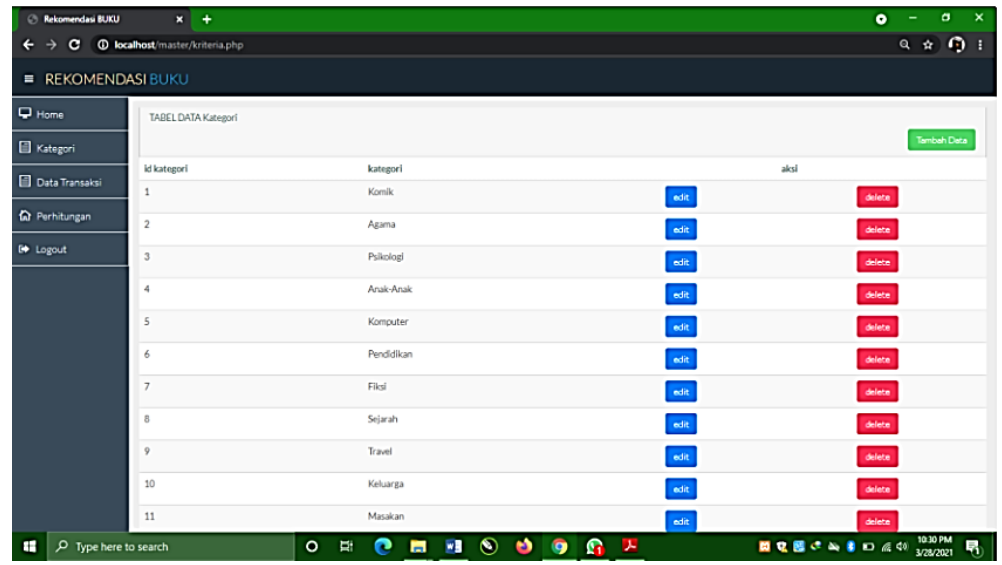

Gambar 4.Tampilan Halaman Kategori

4. Tampilan Halaman Transaksi

Pada tampilan menu transaksi, administrator dapat mengolah data transaksi peminjaman buku di Perpustakaan Ganesa. Tampilan menu transaksi dapat dilihat pada Gambar 5.

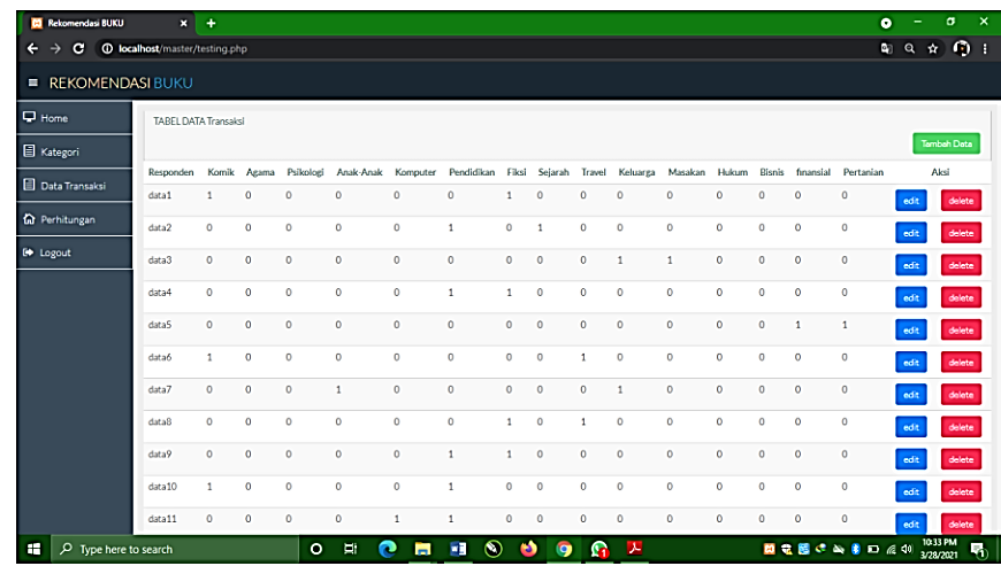

Gambar 5. Tampilan Halaman Transaksi

5. Tampilan Halaman Perhitungan

Pada tampilan menu perhitungan, administrator dapat menentukan minimum support dan minimum confidence, serta menampilkan hasil perhitungan menggunakan algoritma apriori. Tampilan menu perhitungan dapat dilihat pada Gambar 6.

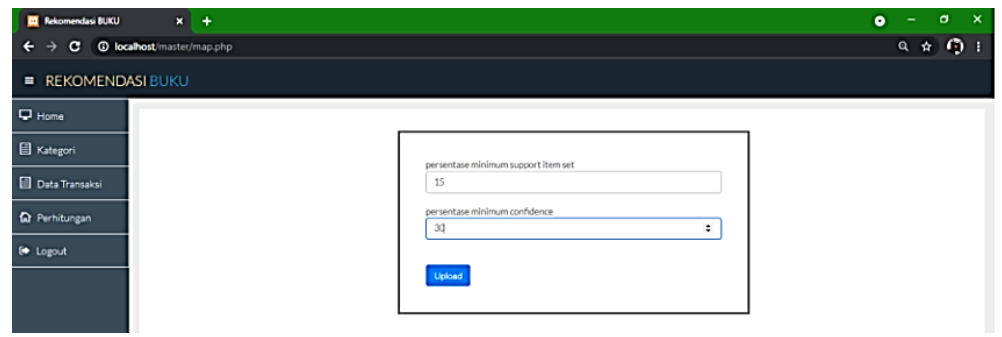

Gambar 6. Tampilan Halaman Perhitungan 


\section{4. Pengujian Sistem}

Pengujian validitas dilakukan dengan menghitung rata-rata keakuratan sistem pada proses perhitungan data transaksi peminjaman buku. Pada perhitungan ini menggunakan aplikasi Tanagra 1.4.50 dengan memasukkan data-data dan diproses menggunakan Algoritma Apriori. Beberapa tahapan yang harus dilakukan untuk menghitung data transaksi ke dalam aplikasi tanagra. Berikut tahap tahap peneliti dalam menghitung data transaksi:

1. Data yang digunakan dalam perhitungan ini merupakan data transaksi peminjaman buku yang sudah terbentuk format tabular dan dimasukkan ke dalam aplikasi Tanagra seperti pada Gambar 7.

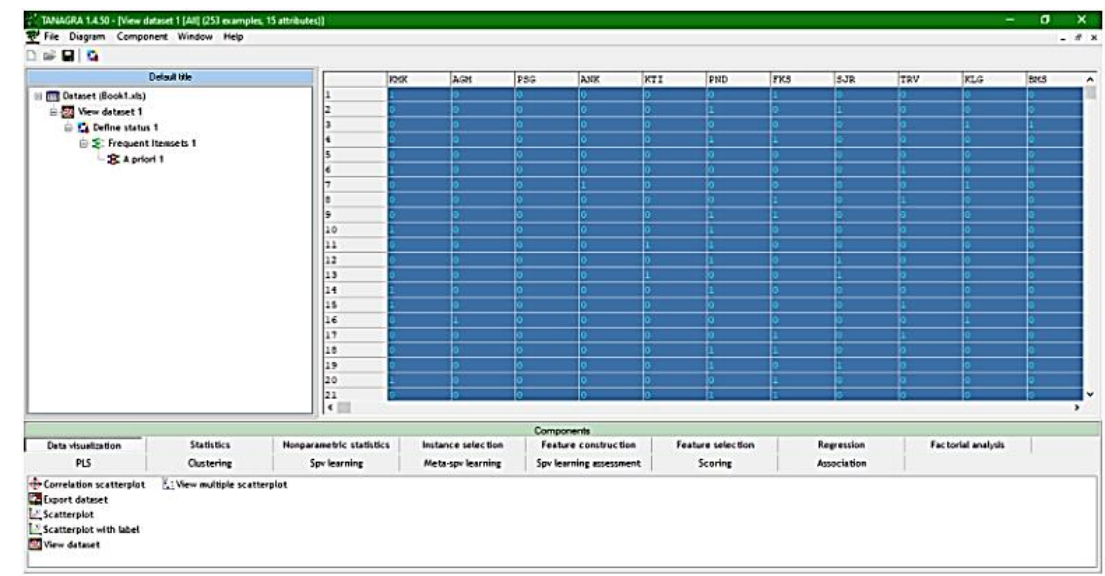

Gambar 7. Dataset Data Transaksi Format Tabular Aplikasi Tanagra

2. Tahapan selanjutnya mendefinisikan status atribut, input parameter data barang dapat dilihat pada Gambar 8.

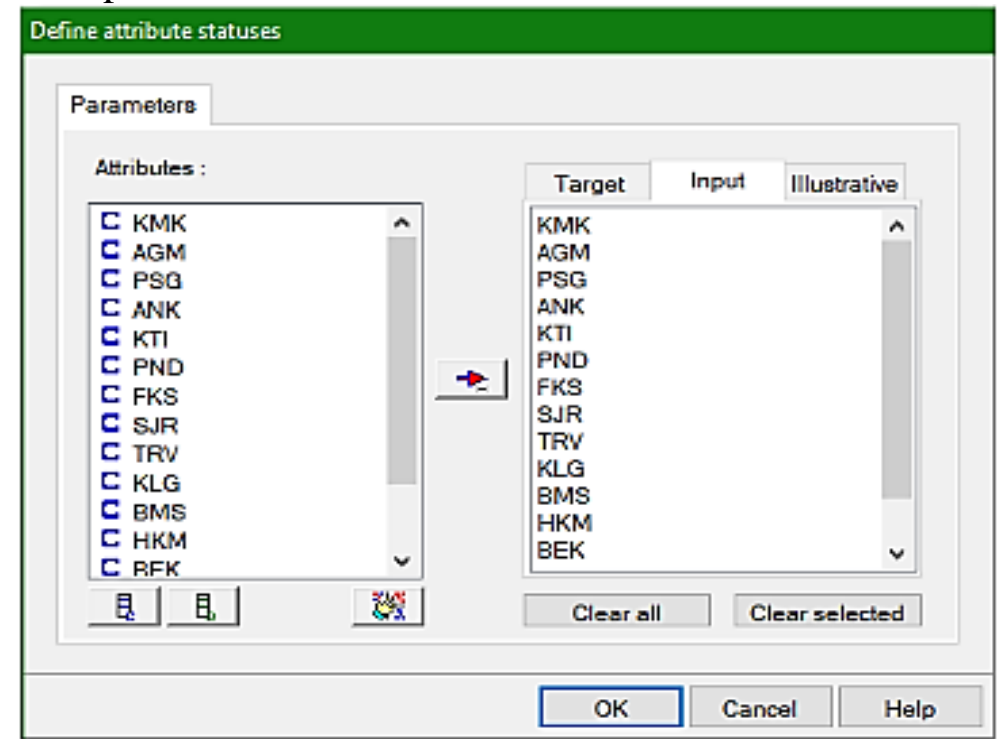

Gambar 8. Definisi Atribut Status Data Aplikasi Tanagra

3. Tahap selanjutnya menghitung frekuensi itemset dengan memasukkan nilai parameter support minimum 15\% maka didapatkan beberapa itemset. Hal ini dapat dilihat pada Gambar 9. 


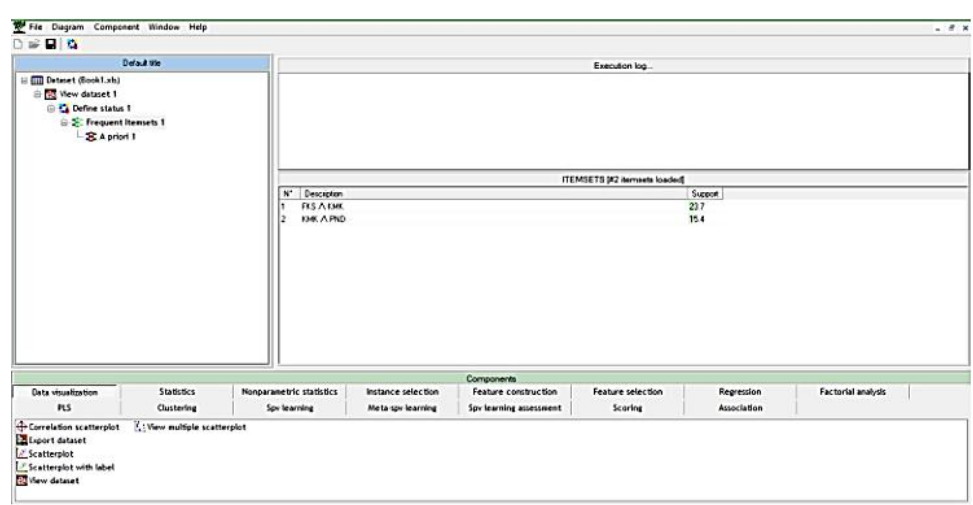

Gambar 9. Nilai Frekuensi Itemset Aplikasi Tanagra

4. Kemudian tahap selanjutnya manghitung dengan algoritma apriori dengan memasukkan nilai parameter minimum support $15 \%$, minimum confidence $30 \%$. Hasil data perhitungan seperti pada Gambar 10.

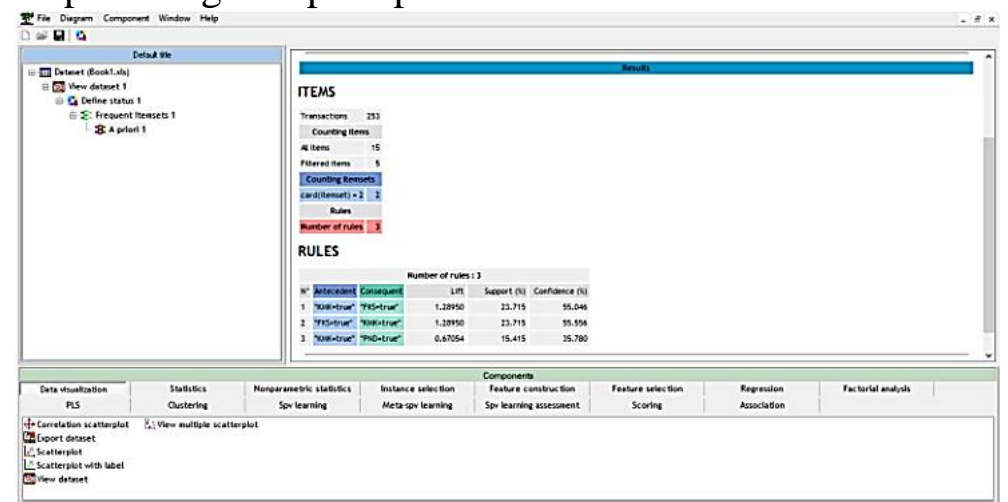

Gambar 10. Hasil Perhitungan Aturan Asosiasi Final Aplikasi Tanagra

Dalam penelitian ini dilakukan pengujian sistem dengan membandingkan hasil rule asosiasi aplikasi yang sudah dibuat dengan aplikasi Tanagra. Dapat diambil kesimpulan bahwa secara perhitungan dan hasil aturan asosiasi final didapatkan sama. Sehingga menghasilkan hipotesa 0 yang berarti tidak terdapat perbedaan hasil perhitungan antara aplikasi yang dibuat dengan aplikasi Tanagra. Hal ini ditunjukan pada Gambar 11.

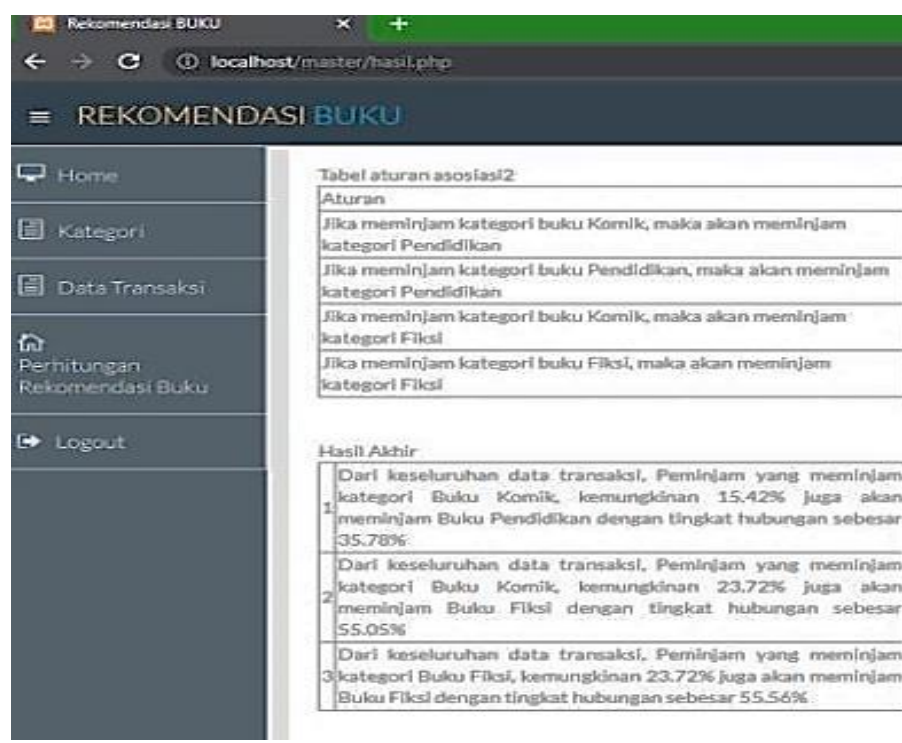

Gambar 11. Hasil Aturan Asosiasi Final Aplikasi 


\section{KESIMPULAN DAN SARAN}

\subsection{Kesimpulan}

Berikut hasil kesimpulan dari penelitian ini telah diselesaikan pembuatan web aplikasi sistem penentuan asosiasi rekomendasi peminjaman buku. Algoritma apriori memanfaatkan data transaksi peminjaman untuk menghasilkan association rule sehingga hasil yang didapatkan tersebut dapat membantu petugas perpustakaan dalam penempatan buku di perpustakaan. Hasil pengujian validitas sistem membuktikan bahwa pola asosiasi valid, dibuktikan dengan pengujian aplikasi Tanagra hasil yang didapatkan 100\% sama, maka data yang diolah dan teknik yang digunakan sudah benar.

\subsection{Saran}

Dari hasil penelitian, ditemukan kelemahan, yaitu data yang akan diuji memiliki persebaran yang tidak seimbang, cenderung pada transaksi dengan satu atau dua buku saja, sehingga rekomendasi yang ditemukan algoritma sedikit. Berdasarkan kelemahan yang ditemukan, saran untuk penelitian selanjutnya menggabungkan data transaksi mingguan ke dalam transaksi dua mingguan untuk dilakukan mining. Penggabungan data ini bisa mengurangi persebaran data yang tidak merata.

\section{DAFTAR PUSTAKA}

Anas, A. (2014). Analisa Pola Peminjaman Buku Perpustakaan menggunakan Algoritma Apriori. Jurnal Edik Informatika (Penelitian Bidang Komputer Sains dan Pendidikan Informatika) Vol 1 No 1, 52-62.

Ariyanti, D. (2020). Data Mining Penerapan Text Mining untuk Klasifikasi. Surabaya: CV. Qiara Media.

Hernawati. (2018). Analisis Market Basket dengan Algoritma Apriori. Ikraith-Informatika Vol 2 No 1, 13-17.

Jollyta, D., Ramdhan, W., \& Zarlis, M. (2020). Konsep Data Mining Dan Penerapan. Yogyakarta: Deepublish.

Lestari, N. (2017). Penerapan Data Mining Algoritma Apriori Dalam Sistem Informasi Penjualan. Jurnal Edik Informatika Vol 3 No 2, 103-114.

Lingga, D. (2016). Penerapan Algoritma Apriori dalam Memprediksi Persediaan Buku pada Perpustakaan SMA Dwi tunggal Tanjung Morawa. Majalah Ilmiah Informasi dan Teknologi Informasi, 18-22.

Persia, A. N., \& Rohmiyati, Y. (2013). Peran Perpustakaan Anak di Rumah Sakit Kanker Jakarta. Jurnal Ilmu Perpustakaan Vol 2 No 3 , 1-8.

Pracoyo, S., \& Seniwati, E. (2021). Algoritma Apriori untuk Penempatan Buku di Perpustakaan SMK Ma'arif 1 Wates. Information System Journal (INFOS) Vol 1 No 2, 1-6.

Sari, R. (2018). Implementasi Algoritma Apriori pada Data Mining untuk Pola Peminjaman Buku di Perpustakaan. Palembang. UIN Raden Fatah .

Siregar, A. M., \& Puspabhuana, A. (2020). Data Mining: Pengolahan Data Menjadi Informasi dengan Rapidminer. Sukoharjo: CV. Kekata Group. 
Suendri, Ikhwan, A., \& Hutabarat, A. A. (2021). Data Mining Algoritma FB-Growth : Analisis Pola Pencurian Daya Listrik. Jakarta: Amerta Media.

Tahyudin, I., Putra, I. M., \& Syafa'at, A. Y. (2021). Data Mining dan Data Warehouse Menggunakan Aplikasi Knime. Banyumas: Zahira Media Publisher.

Vulandari, R. T. (2017). Data Mining Teori dan Aplikasi Rapidminer. Yogyakarta: CV Gava Media. 